\title{
Configuration-based Compliance Control of Kinematically Redundant Robot Arm Part II - Experimental Validation
}

\author{
Petar B. Petrovic \\ Full professor \\ University of Belgrade \\ Faculty of Mechanical Engineering \\ Department of Production Engineering \\ Ivan R. Danilov \\ Ph.D student \\ University of Belgrade \\ Faculty of Mechanical Engineering \\ Department of Production Engineering
}

\begin{abstract}
This two-part paper presents an approach to the control of robot endpoint compliance, i.e., elasto-mechanical interaction between a robot and its environment using kinematic redundancy instead of actuation redundancy. In Part I this approach is developed by proposing the Configuration-based Stiffness Control (CSC) method for kinetostatically consistent control of robot compliant behaviour, based on the gradient projection of the cost function which minimizes the norm of off-diagonal elements of the jointspace matrix. In Part II validity of the proposed compliance control method is tested by simulation experiments using as a simulation platform two specific cases of most simple kinematically redundant robot arms: Case 1 - experiments with onedimensional taskspace $(m=1)$ and minimal possible redundancy, $r=(n-m)=1$, and Case 2 - experiments with onedimensional taskspace $(m=1)$ and minimal possible hyper-redundancy, $r=2$ and $r>m$. In both cases the singularity and joint limits were not considered.
\end{abstract}

Keywords: Kinematic redundancy, Compliance control, Nullspace.

\section{INTRODUCTION}

The effectiveness of the Configuration-based Stiffness Control (CSS) framework in kinetostatic domain which is proposed and analytically formulated in Part 1 of this paper was extensively verified by computer simulations using planar, kinematically redundant anthropomorphic robot arms. Two characteristic sets of experiments were performed:

Case \#1: Experiments with minimal redundancy, $r=(n-m)=1$, where $m$ is the dimension of the robot taskspace and $n$ is the dimension of the robot joint space respectively, in order to provide simplest possible analytical mathematical apparatus and,

Case \#2: Experiments with $r=2$, with an intent to enter the domain of hyper redundant robots, i.e., when $r>m$, which is important to gain practical knowledge about the influence of robot higher nullspace dimensionality to the proposed Configuration-based Stiffness Control (CSC) method.

In both cases, for simplicity / clarity but without loss of necessary generality, the smallest possible dimension of the taskspace was adopted with only one translation along the $x_{1}$ Cartesian coordinate, $m=1$.

Singularity and joint limits were not considered in

Received: November 2016, Accepted: February 2017, Correspondence to: Petar B. Petrovich, Full professor Faculty of Mechanical Engineering,

Kraljice Marije 16, 11120 Belgrade 35, Serbia

E-mail: pbpetrovic@mas.bg.ac.rs

doi:10.5937/fmet1704475P

(C) Faculty of Mechanical Engineering, Belgrade. All rights reserved both cases.

The remainder of this paper is organized as follows: the analytical model (expressed as a set of closed-form analytic functions) and simulation results of the Case \#1 - MRR-R1 robot, are presented in section 2, and, due to its complexity, a reduced analytical model and simulation results of the Case \#2 - MRR-R2 robot, are presented in section 3. The paper ends with the conclusion given in section 4 .

\section{SIMULATION EXPERIMENTS - CASE \#1}

Case \#1 is in fact a Minimal Redundancy Robot with one redundant d.o.f. - MRR-R1 robot. Geometric model of the robot arm and its taskspace is shown in Fig. 1a.

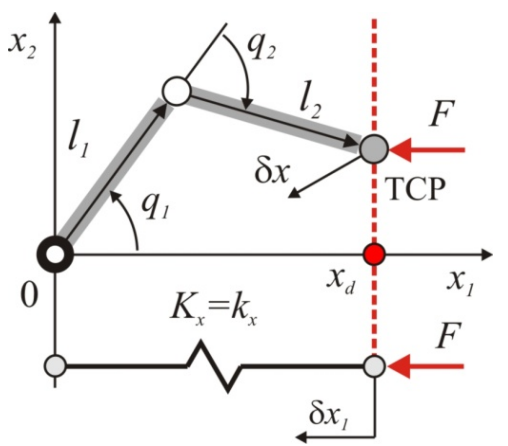

Figure 1. Model of the Minimal Redundancy robot MRR-R1 in adopted taskspace.

The analytic equations that follow, use the following abbreviations for trigonometric functions:

$$
\begin{aligned}
& \sin \left(q_{1}\right)=s_{1}, \cos \left(q_{1}\right)=c_{1} \\
& \sin \left(q_{1}+q_{2}\right)=s_{12}, \cos \left(q_{1}+q_{2}\right)=c_{12}, \text { and }
\end{aligned}
$$


$\sin \left(q_{1}+q_{2}+q_{3}\right)=s_{123}, \cos \left(q_{1}+q_{2}+q_{3}\right)=c_{123}$.

The geometric model, the Jacobian matrix and the forward kinematic model of the MRR-R1 robot are:

$$
\begin{gathered}
x_{1}=f(q)=l_{1} c_{1}+l_{2} c_{12}, \\
J(q)=\left[\begin{array}{ll}
J_{1,1}(q) & J_{1,2}(q)
\end{array}\right]= \\
=\left[\begin{array}{ll}
-\left(l_{1} s_{1}+l_{2} s_{12}\right) & -l_{2} s_{12}
\end{array}\right], \\
\delta x_{1}=\left[\begin{array}{ll}
-\left(l_{1} s_{1}+l_{2} s_{12}\right) & -l_{2} s_{12}
\end{array}\right]\left[\begin{array}{l}
\delta q_{1} \\
\delta q_{2}
\end{array}\right] .
\end{gathered}
$$

According to relation (16) from the Part 1 of this paper (further referencing of equations from the Part 1 will abbreviated by adding the /Part1 after the equation number, i.e., (16/Part1)), the Moore-Penrose pseudoinverse of the Jacobian matrix (1b), [1] and the corresponding inverse kinematic model are:

$$
\begin{aligned}
& J(q)^{+}=\left[\begin{array}{c}
J_{1,1}^{+}(q) \\
J_{2,1}^{+}(q)
\end{array}\right]=\left[\begin{array}{c}
\frac{J_{1,1}(q)}{J_{1,1}^{2}(q)+J_{1,2}^{2}(q)} \\
\frac{J_{1,2}(q)}{{J_{1,1}{ }^{2}(q)+J_{1,2}^{2}(q)}^{2}}
\end{array}\right], \\
& {\left[\begin{array}{l}
\delta q_{1} \\
\delta q_{2}
\end{array}\right]==-\frac{1}{\left(l_{1} s_{1}+l_{2} s_{12}\right)^{2}+\left(l_{2} s_{12}\right)^{2}}\left[\begin{array}{c}
l_{1} s_{1}+l_{2} s_{12} \\
l_{2} s_{12}
\end{array}\right] \delta x_{1}}
\end{aligned}
$$

Then, the rangespace of the Jacobian pseudoinverse (2), [2] is:

$$
R\left(J^{+}\right)=\delta q_{1}=\frac{J_{1,1}^{+}(q)}{J_{2,1}^{+}(q)} \delta q_{2}=\frac{l_{1} s_{1}+l_{2} s_{12}}{l_{2} s_{12}} \delta q_{2} .
$$

The Jacobian matrix (1b) can be transformed into the equivalent reduced row echelon form [3], [4]:

$$
\begin{gathered}
N(J(q))=\operatorname{rref}(J(q))=\left[\begin{array}{ll}
1 & a_{x}
\end{array}\right] \\
a_{x}=a_{x}(q)=\frac{J_{1,2}(q)}{J_{1,1}(q)}=\frac{l_{2} s_{12}}{l_{1} s_{1}+l_{2} s_{12}}
\end{gathered}
$$

and then the corresponding nullspace equation can be obtained by substituting (4b) into relation (12/Part1):

$$
N(J): \delta q_{1}=-\frac{J_{1,2}(q)}{J_{1,1}(q)} \delta q_{2}=-\frac{l_{2} s_{12}}{l_{1} s_{1}+l_{2} s_{12}} \delta q_{2}
$$

It is obvious that the rangespace (4a) and the nullspace (4c) of the Jacobian matrix are straight lines, passing through the origin of the robot configuration space. Furthermore, these lines are mutually orthogonal, which is expected from the definition of the MoorePenrose pseudoinverse (minimum norm pseudoinverse).

Based on equations (14/Part1) and (15/Part1) the nullspace complementary projector is expressed by the equation (5), [5], [6], which finally leads us to the component (6) of the nullspace vector $\delta q_{0 N}$ that governs the execution of the secondary control task, i.e., shapes the generalized stiffness matrix of the robot TCP.

Fundamental spaces (4a) and (4c) of the Jacobian matrix (1b), particular solution (3) and homogeneous solution (6) of the Jacobian matrix (1b), as well as the mechanism of the task fusion achieved through the relation (13/Part1), are shown graphically in Fig. 2.

$$
u(q)=k_{x}\left\|J_{1,1}(q) J_{1,2}(q)\right\|=k_{x} l_{2} s_{12}\left(l_{1} s_{1}+l_{2} s_{12}\right),
$$

and then, using relation (20/Part1), one finally derives the gradient optimization function expressed as closed form analytic equation by ( $8 b)$.

Since the dimension of the taskspace $m=1$, the corresponding stiffness matrix is a scalar, i.e. $K_{x}=k_{x}$, and consequently, by applying relation (8/ Part 1$)$, the jointspace stiffness matrix takes the form given by (7).

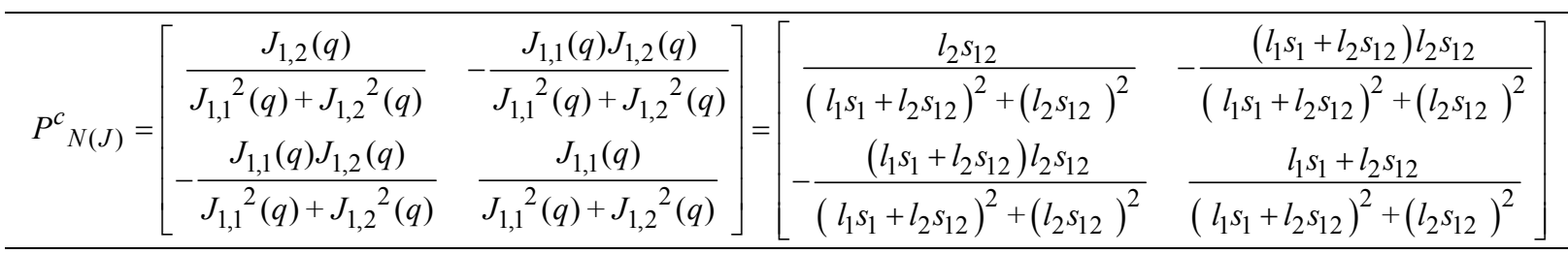

$$
\delta q_{0 N}=\left[1-J^{+}(q) J(q)\right] \delta q_{0}=\left[\begin{array}{ll}
\delta q_{0 N 1} & \delta q_{0 N 2}
\end{array}\right]^{T}
$$

$$
\begin{aligned}
& \delta q_{0 N 1}=\frac{J_{1,2}(q)}{J_{1,1}^{2}(q)+{J_{1,2}}^{2}(q)} \delta q_{01}+-\frac{J_{1,1}(q) J_{1,2}(q)}{{J_{1,1}}^{2}(q)+{J_{1,2}}^{2}(q)} \delta q_{02}=\frac{l_{2} s_{12}}{\left(l_{1} s_{1}+l_{2} s_{12}\right)^{2}+\left(l_{2} s_{12}\right)^{2}} \delta q_{01}+\frac{-\left(l_{1} s_{1}+l_{2} s_{12}\right) l_{2} s_{12}}{\left(l_{1} s_{1}+l_{2} s_{12}\right)^{2}+\left(l_{2} s_{12}\right)^{2}} \delta q_{02} \\
& \delta q_{0 N 2}=-\frac{J_{1,1}(q) J_{1,2}(q)}{{J_{1,1}}^{2}(q)+{J_{1,2}}^{2}(q)} \delta q_{01}+\frac{J_{1,1}(q)}{{J_{1,1}}^{2}(q)+J_{1,2}^{2}(q)} \delta q_{02}=\frac{-\left(l_{1} s_{1}+l_{2} s_{12}\right) l_{2} s_{12}}{\left(l_{1} s_{1}+l_{2} s_{12}\right)^{2}+\left(l_{2} s_{12}\right)^{2}} \delta q_{01}-\frac{l_{1} s_{1}+l_{2} s_{12}}{\left(l_{1} s_{1}+l_{2} s_{12}\right)^{2}+\left(l_{2} s_{12}\right)^{2}} \delta q_{02}
\end{aligned}
$$

$$
K_{q}=k_{x}\left[\begin{array}{cc}
J_{1,1}^{2}(q) & J_{1,1}(q) J_{1,2}(q) \\
J_{1,1}(q) J_{1,2}(q) & J_{1,2}^{2}(q)
\end{array}\right]=k_{x}\left[\begin{array}{cc}
\left(l_{1} s_{1}+l_{2} s_{12}\right)^{2} & l_{2} s_{12}\left(l_{1} s_{1}+l_{2} s_{12}\right) \\
l_{2} s_{12}\left(l_{1} s_{1}+l_{2} s_{12}\right) & \left(l_{2} s_{12}\right)^{2}
\end{array}\right]
$$

$$
\delta q_{0}=\left[\begin{array}{l}
\delta q_{01} \\
\delta q_{02}
\end{array}\right]=-\alpha \nabla u(q)=-\alpha \frac{\partial}{\partial q}\left[k_{x} l_{2} s_{12}\left(l_{1} s_{1}+l_{2} s_{12}\right)\right]=\alpha\left[\begin{array}{c}
-k_{x} \sin \left(2 q_{1}+2 q_{2}\right) l_{2}^{2}-k_{x} l_{1} \sin \left(2 q_{1}+q_{2}\right) l_{2} \\
-k_{x} l_{2} \cos \left(q_{1}+q_{2}\right)\left(2 l_{2} \sin \left(q_{1}+q_{2}\right)+l_{1} \sin \left(q_{1}\right)\right)
\end{array}\right]
$$




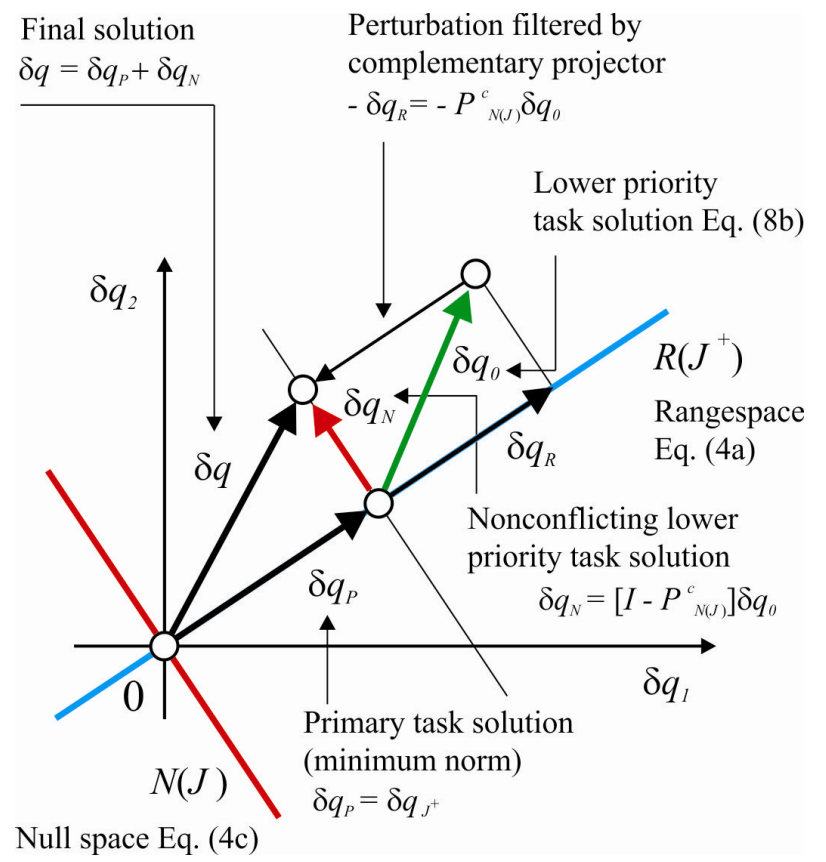

Figure 2. Kinetostatic mappings in the MRR-R1 robot jointspace, derived from (13 /Part1) and derived analytic closed-form expressions of its rangespace and nullspace.

According to the Proposition \#2 which is postulated in the Part 1 of this paper, and the relation (19/Part1), the cost function is defined as follows:

The scalar potential field generated by the cost function (8a) is shown in Fig. 3. The stream lines which are calculated using relation $(8 \mathrm{~b})$ are also shown in Fig. 3 . It is obvious that the potential field (8a) is wellbehaved and the corresponding stream lines converge steadily to the nearest local minima. The adopted link parameters for the MRR-R 1 robot are: $l_{1}=0.36 \mathrm{~m}$ and $l_{2}=0.7 l_{1}=0.252 \mathrm{~m}$.

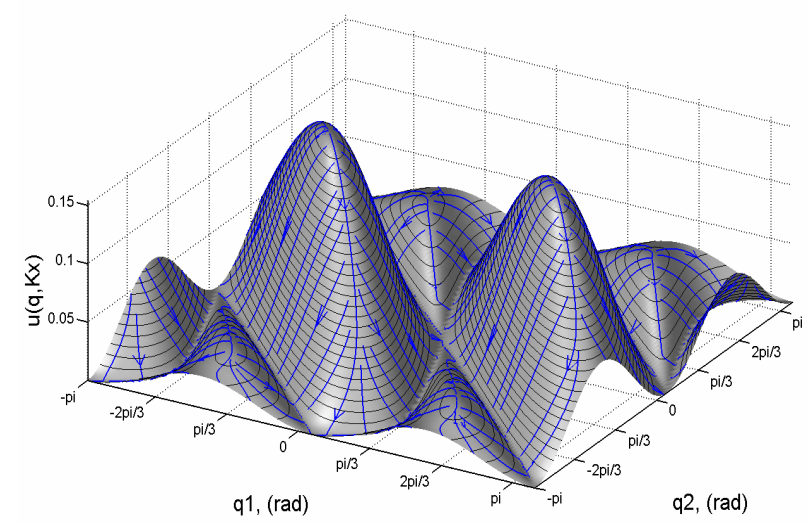

Figure 3. Potential field and the corresponding streamlines generated by equations ( $8 a$ ) and ( $8 b)$.

The TCP stiffness map over the entire jointspace is shown in Fig. 4. This stiffness map is derived using equation (17/Part1) and the jointspace stiffness matrix (7/Part1), which is reduced to its diagonal elements only (off-diagonal elements are simply disregarded because MRR-R1 robot is not able to generate them physically).

The desired TCP stiffness is set to $k_{x d}=1$. The value of TCP stiffness associated with the MRR-R1 robot varies in the range $\left[0.5 k_{x d}, k_{x d}\right]$ and is highly configuration dependent. Since there exists at least one configuration subspace $Q \subseteq \mathrm{N}(J(q))$ with a nonempty set of configurations $q^{*} \in Q \wedge Q \neq \varnothing$ which simultaneously satisfies constraints 2 and 3 declared by the Proposition \#1, postulated in the Part 1 of this paper, it is clear that the hypothesis which is associated to this proposition holds partially for the MRR-R1 robot. To prove its completeness it is necessary to test the consistency of the $q^{*} \in Q$ with the constraint 1 . For that purpose a series of simulation experiments were performed based on integration scheme $(21 /$ Part 1$)$ and the taskspace integration step set to $\delta q_{x}=0.001 \mathrm{~m}$. Two specific simulation cases are shown in Fig. 5 and Fig 6. The first one (Fig. 5) is related to the case when both, primary and secondary tasks are active and when the value of $\beta$ multiplier of the $\alpha$ operator (20/Part1) is set to 1 . The second one (Fig. 6) is related to the case when the control system is given only the primary task.

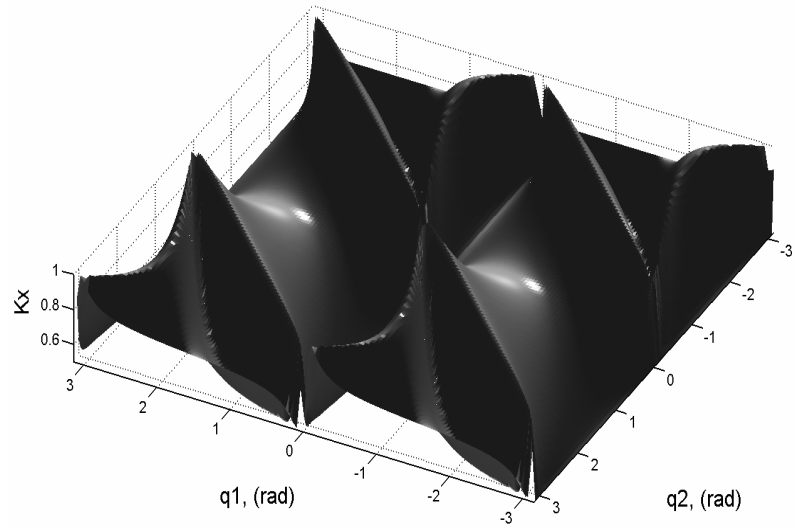

Figure 4. Stiffness map of the MRR-R1 robot for the desired TCP stiffness set to $k_{x d}=1$.

Comparative analysis of the simulation results shown in Fig. 5 and Fig. 6 obviously confirms functionality of the proposed Configuration-based Stiffness Control framework. The TCP motion of the MRR-R1 robot mechanism shown in Fig. 1, leads to the conclusion that the task fusion machine (13/Part1) effectively accomplishes both the primary and secondary task, with stable convergence to the secondary task optimum, governed by the cost function $(19 /$ Part 1$)$ and the corresponding nullspace motion generator (20/Part1). The convergence of the secondary task to its optimal value is faster than the convergence of the primary task, i.e., the optimal value of the TCP stiffness $k_{x}=k_{x d}$ is achieved in the integration step $k=241$, while the TCP desired position $x_{d}$ is achieved in the integration step $k=359$, even though the norms of the particular and nullspace displacement are the same (according to (22/Part1) and $\beta=1)$. It is important to underline that once achieved, the secondary task optimum remains stable, i.e., unaffected by the successive changes of the robot configuration before the primary task is completed (integration step $k=359$ ).

The results obtained from the performed simulation experiments clearly show that the constraint 1 of the Proposition \#1 can be simultaneously satisfied with constraints 2 and 3 by the proposed CSC framework in the kinetostatic domain. This proves the validity of the Proposition \#1 from the Part 1 of this paper for the MRR-R1 robot. 
a)

b)
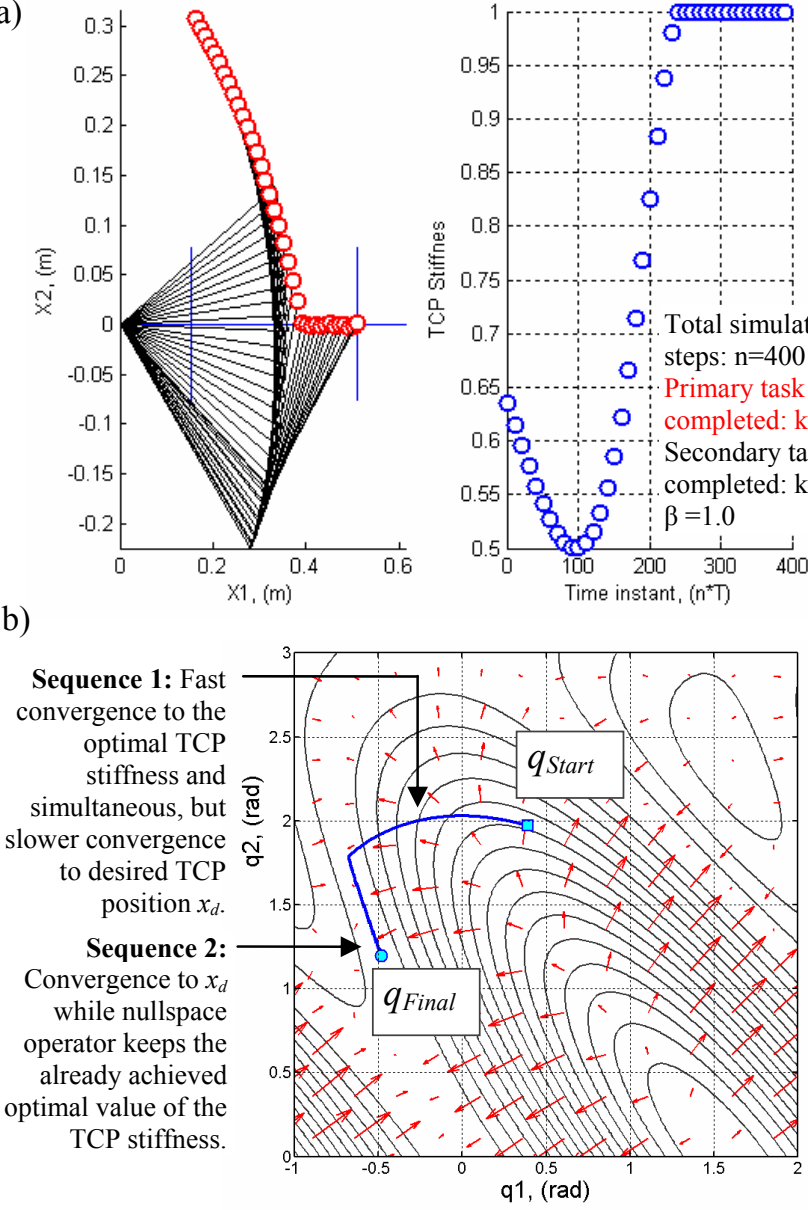

Figure 5. Simulation results of the MRR-R1 robot motion from $x_{0}=\left(l_{1}+l_{2}\right) / 4=0.153 \mathrm{~m}$ up to $x_{d}=\left(l_{1}+l_{2}\right) / 1.2=0.510 \mathrm{~m}$ and execution of the secondary task - optimization of the TCP stiffness: a) Robot mechanism motion in the operational space; b) TCP stiffness variation; c) robot TCP motion in the configuration space (isopotential lines and corresponding gradients of the cost function potential field are shown in the background of the plot).

\section{SIMULATION EXPERIMENTS - CASE \#2}

Case \#2 is in fact a Minimal Redundancy Robot with two redundant d.o.f. - MRR-R2 robot. Experimentation with MRR-R2 robot, $(m=1, r=2)$, enters the domain of highly redundant robots, i.e., when $r>m$, which is important to gain practical knowledge about the influence of robot nullspace dimensionality to complexity of the proposed Configuration-based Stiffness Control (CSC) method.

Model of the robot arm and its taskspace is shown in Fig. 7a. Although it is still a very simple robot arm, additional degrees of freedom significantly increase complexity of its analytical model, which is therefore omitted from further consideration. Instead, only the most relevant results will be given. First of all, it is the volume potential field which is generated by the cost function (19/Part1) using the adopted set of link parameters: $l_{1}=0.360 \mathrm{~m}, l_{2}=0.360$ and $l_{3}=0.275 \mathrm{~m}$. The potential field is shown in Fig. 7b. In order to depict its internal dynamics along the $q_{1}$ direction, an orthogonal slice at the arbitrarily chosen point $q_{1}=\pi / 2$ is given in Fig. 7c. The field segment shows that the adopted a)
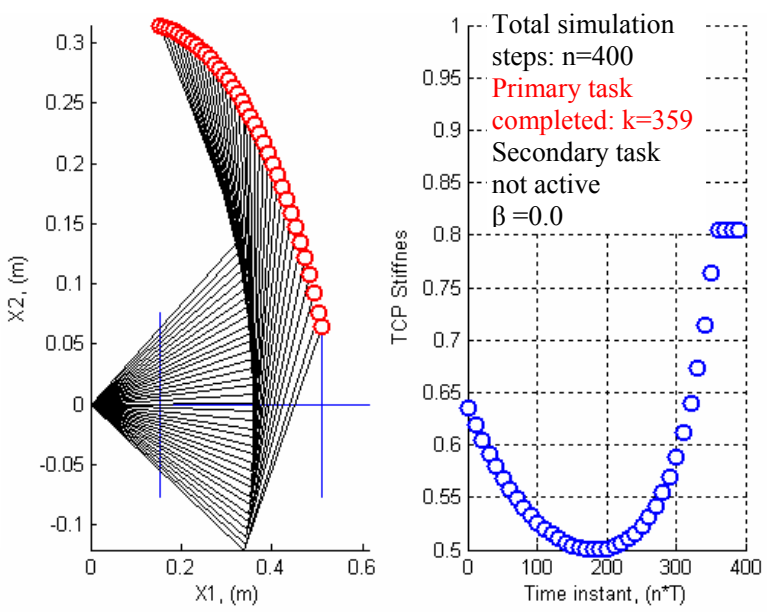

b)

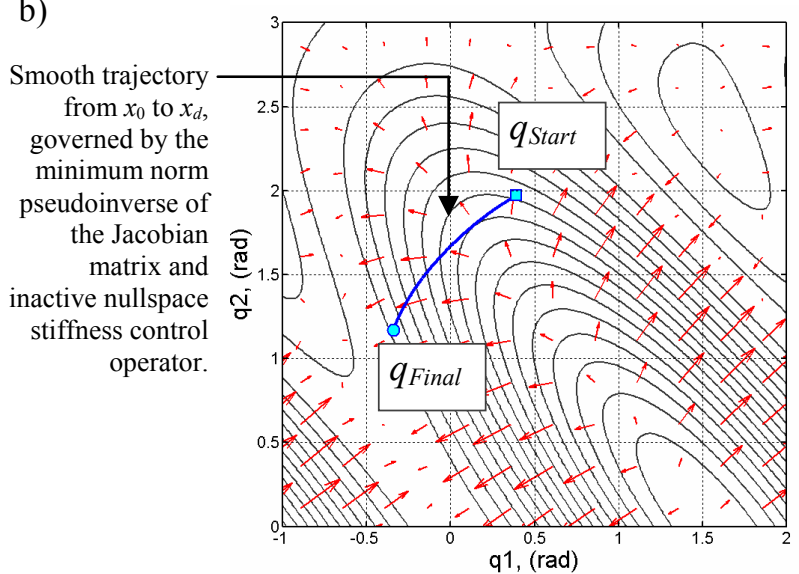

Figure 6. Simulation results of the MRR-R1 robot motion from $x_{0}=\left(l_{1}+l_{2}\right) / 4=0.153 \mathrm{~m}$ up to $x_{d}=\left(l_{1}+l_{2}\right) / 1.2=0.510 \mathrm{~m}$ with the inactive secondary task - optimization of the TCP stiffness: a) Robot mechanism motion in the operational space; b) TCP stiffness variation; c) robot TCP motion in the configuration space (isopotential lines and corresponding gradients of the cost function potential field are shown in the background of the plot).

potential field is generally well-behaved. The corresponding streamlines are smooth and strongly converge to local minima.

Compared with the MRR-R1 robot, the two redundant d.o.f. radically increase the capacity of the MRR-R2 linkage to generate the desired TCP stiffness. This is illustrated graphically in Fig. 8c, which shows the same potential field of MRR-R2 as in Fig. $7 b$, only reduced to the subspace $u\left(q, K_{x}\right) \leq u_{B}$ where $u_{B}$ is a boundary isopotential surface satisfying $u_{B}=$ $0.03\left(\max \left(u\left(q, K_{x}\right)\right)\right.$. This subspace corresponds to the configurations which induce TCP stiffness very close or equal to the desired value, and is conditionally related to the subspace $Q$ defined by the Proposition \#1 which is postulated in Part 1 of this paper.

A series of simulation experiments were performed in order to prove the functionality of the proposed CSC framework with MRR-R2 robot arm. As an example, Fig. $8 \mathrm{a}$ and $8 \mathrm{~b}$ show the results of the simulation of the case when both tasks were active and when the value of the $\beta$ multiplier was set to 2 in order to speed up the convergence of the secondary task toward the optimal value of the TCP stiffness. In both tasks the operators 
abnverge steadily to optimal/desired values. However, it is obvious that after the convergence of the secondary task (iteration $k=305$ ) dithering motions occur, which significantly influence the robot TCP, causing crosstalk between the secondary and the primary task.

b)

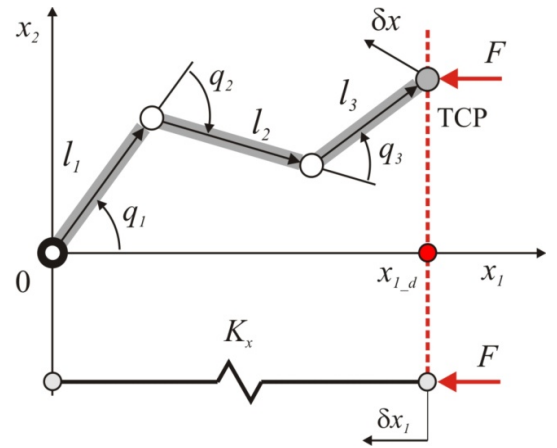

c)

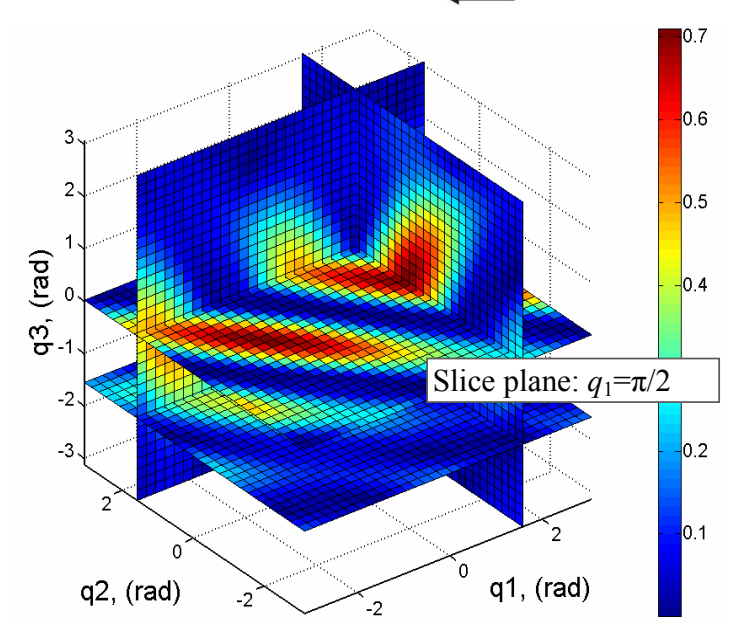

d)
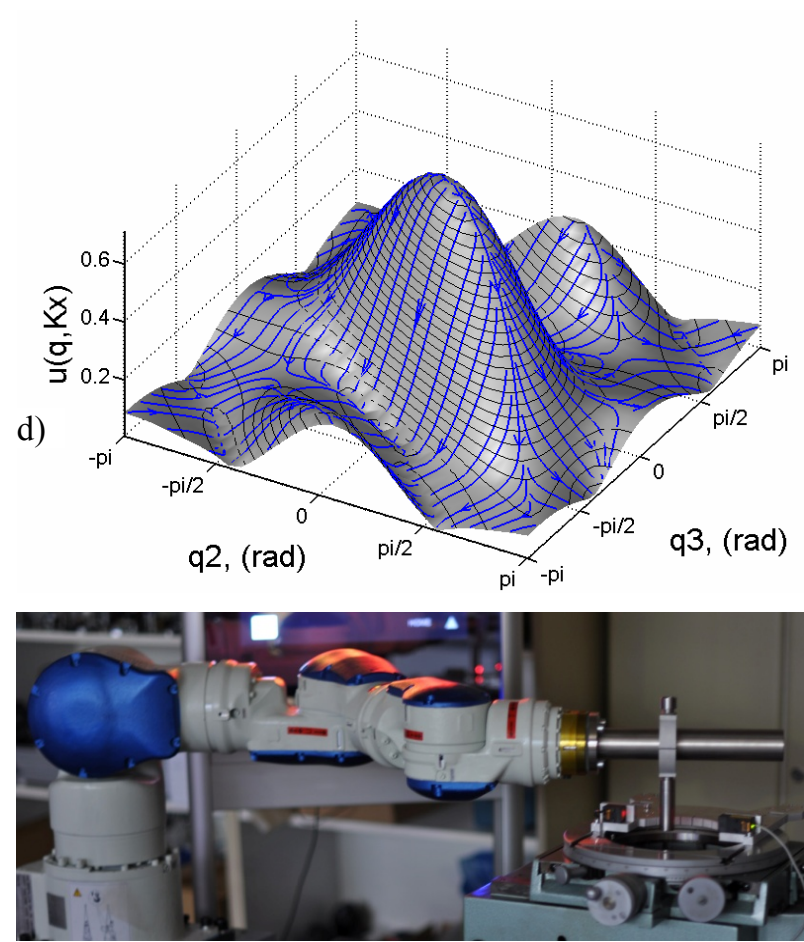

Figure 7. Geometrical model of the minimal redundant robot MRR-R2 in the taskspace (a) and the corresponding volume potential field (b). Potential field dynamic along the $q_{1}$ direction for slice plane $q_{1}=\pi / 2$, with the corresponding streamlines (c). Yaskawa SIA-10F, 7 d.o.f. anthropomorphic robot arm used in simulations (kinematically reduced to 3 d.o.f. in horizontal plane to avoid influence of gravitational terms), (d).
Such behaviour is observed when the secondary task reaches its optimal value, when the nullspace motion generator becomes unstable due to sudden changes in the gradient sign $(20 /$ Part 1$)$. This problem could be partially solved by low-pass filtering. However, a more comprehensive solution requires introduction of additional secondary tasks, first of all the task which avoids singularities (an additional constraint which is highly repulsive in the neighbourhood of singular configurations) or at least the damped least squares solution, [7], for pseudoinverse (16/Part1), [1], [2].

a)
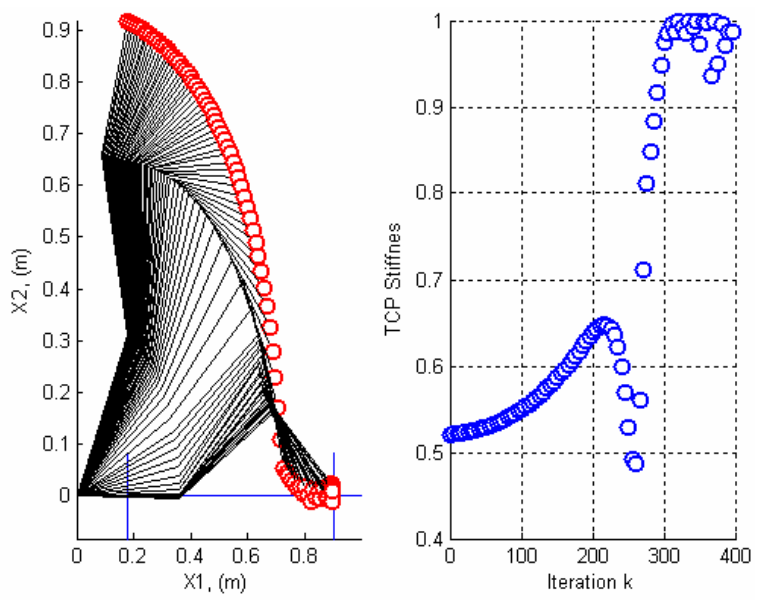

b)

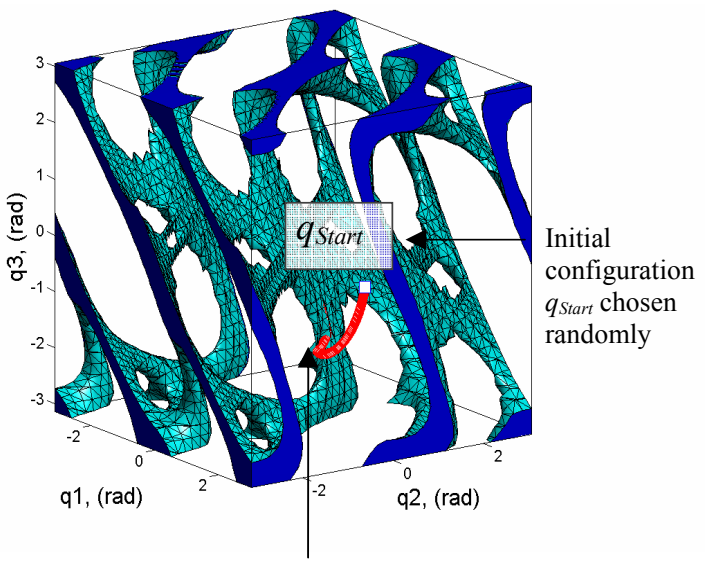

Trajectory towards the configuration which is task consistent, i.e., satisfies primary and secondary task simultaneously. The trajectory ended in the subspace of configurations which generate zero or almost zero error of induced TCP stiffness.

Figure 8. Simulation results for the MRR-R2 robot motion from $x_{0}=0.180 \mathrm{~m}$ up to $x_{d}=0.900 \mathrm{~m}$, and execution of the secondary task - optimization of the TCP stiffness: a) Robot mechanism motion in the operational space; b) TCP stiffness variation; $c)$ subspace of the scalar potential field satisfying $u\left(q, K_{x}\right)<0.03\left[\max \left(u\left(q, K_{x}\right)\right)\right]$, extracted from Fig. $7 \mathrm{~b}$, and robot motion in the configuration space.

\section{CONCLUSION}

In this two part paper, the Configuration-based Stiffness Control (CSC) method is formulated as a kinetostatically consistent framework for robot compliant behaviour control, based on gradient projection of the cost function which minimizes the norm of off-diagonal elements of the jointspace matrix. Part 2 is related to experimental validation of the 
proposed CSC method. Using two simplest forms of redundant robots we have found by computer simulation as follows: a) Kinematic redundancy and nullspace of the corresponding Jacobian matrix are potentially applicable for effective control of robot TCP compliant behaviour by canonization of the joint stiffness matrix. High degree of kinematic redundancy, i.e., $r>1$ or in particular, when $\mathrm{r}>\mathrm{m}$ is essential to achieve good kineto-static performances; b) Euclidian norm of offdiagonal entries of the joint stiffness matrix can be effectively used for construction of a potential function for optimization of the robot nullspace stiffness in order to generate best possible approximate of desired robot TCP stiffness matrix; c) Problem of computational complexity requires soft-computing (approximate reasoning) and similar techniques to be used, in particular designed for real-applications (non-iterative), [8]. Further research in that direction is necessary.

\section{ACKNOWLEDGMENT}

This work is carried out within the project: Smart Robotics for Customized Manufacturing, supported by the Serbian Ministry for Education and Science, Grant No. TR35007.

\section{REFERENCES}

[1] Yanai, H., Takeuchi, K., and Takane, Y.: Projection Matrices, Generalized Inverse Matrices, and Singular Value Decomposition, Springer Science+Business Media, ISBN 978-1-4419-98866, 2011.

[2] Baerlocher, P, Boulic, R.: An Inverse Kinematic Architecture Enforcing an Arbitrary Number of Strict Priority Levels, The Visual Computer, Vol. 20, No. 6, pp. 402-417, 2004.

[3] Meyer, C. D.: Matrix Analysis and Applied Linear Algebra, Society for Industrial and Applied Mathematics (SIAM), John Wiley and Sons, Philadelphia, 2001

[4] Leo, S. J.: Linear Algebra With Applications (8th ed.), Pearson Prentice Hall, New Jersey, 2006.

[5] Liegeois, A.: Automatic supervisory control of the configuration and behavior of multibody mechanisms, IEEE Transactions on Systems, Man and Cybernetics, Volume 7, No. 12, pp: 868-871, 1977.
[6] Baillieul, J., Hollerbach, J., and Brockett, R.W.: Programming and Control of Kinematically Redundant Manipulators, 23-rd IEEE Conf. on Decision and Control, Las Vegas, p.768-774, 1984.

[7] Deo, A. S., Walker, I. D.: Overview of Damped Least-Squares Methods for Inverse Kinematics of Robot Manipulators, Journal of Intelligent and Robotic Systems, Vol. 14, No. 1, pp. 43-68, 1995.

[8] Petrovic, P. B.: Outline of a New Feature Space Deformation Approach In Fuzzy Pattern Recognition, FME Transactions, Vol. 31, No. 2, pp. 75-86, 2003.

\section{УПРАВЉАЊЕ ПОПУСТЉИВОСТИ КИНЕМАТСКИ РЕДУНДАНТНЕ РОБОТСКЕ РУКЕ ПРОМЕНОМ КОНФИГУРАЦИЈЕ} Део II - Експериментална провера

\section{П. Петровић, И. Данилов}

У оквиру овог рада који се састоји из два дела, приказује се нови приступ управљања попустљивошћу врха робота, односно еластомеханичком интеракцијом врха робота и његовог окружења, применом кинематске редундансе уместо актуационе. У првом делу овај приступ је приказан кроз конципирање методе управљања крутошћу променом конфигурације Configuration-based Stiffness Control (CSC), за случај кинетосатичке конзистентности, применом пројекције градијента оптимизационе функције која минимизира Еуклидову норму недијагоналних елемената матрице крутости робота изражене у унутрашњим координатама. $\mathrm{y}$ другом делу предложена метода управљања попустљивошћу је тестирана симулационим експериментима, користећи као симулациону платформу два посебна случаја најједноставнијих кинематски редундантних роботских руку: Случај 1 - експерименти са једнодимензионим радним простором $(m=1)$ и минимално могућом редундансом, $r=(n-m)=1$, и Случај 2 - експерименти са једнодимензионим радним простором $(m=1)$ и минимално могућом хиперредундансом, $r=2$ и $r>m$. У оба случаја сингуларитети и ограничења у опсезима покретљивости зглобова нису разматрани. 